\title{
Modeling Effectiveness of Financial Support for the Social Capital Development in Economic Emergence
}

\author{
VIKTORIYA HUROCHKINA \\ Department of Enterprise Economics, \\ University of the State Fiscal Service of \\ Ukraine, Irpin, 31, Universytetska str. \\ UKRAINE
}

\author{
SVITLANA RESHMIDILOVA \\ Department of Marketing and Trade \\ Entrepreneurship, Khmelnytsky National \\ University, Khmelnytsky, 11, Instytutska str. \\ UKRAINE
}

\author{
LIUDMYLA BOHATCHYK \\ Department of Accounting, Auditing and \\ Taxation, Khmelnytsky National University, \\ Khmelnytsky, 11, Instytutska str. \\ UKRAINE
}

\author{
ANATOLY TELNOV \\ Department of Marketing and Trade \\ Entrepreneurship, Khmelnytsky National \\ University, Khmelnytsky, 11, Instytutska str. \\ UKRAINE
}

\author{
LARYSA SKOROBOGATA \\ Head of Department of Accounting, Auditing \\ and Taxation, Khmelnytsky National \\ University, Khmelnytsky, 11, Instytutska str. \\ UKRAINE
}

\author{
NATALIA RIABININA \\ Department of Enterprise Economics, \\ University of the State Fiscal Service \\ of Ukraine, Irpin, 31, Universytetska str. \\ UKRAINE
}

\begin{abstract}
The article explores the components of the system of social capital development in the economic emergence, which focus on the financial provision of social protection and social interaction in professional activities. In order to identify the impact of the effectiveness of the implementation of the country's social policy on the development of social capital through the achievement of systemic effects (synergistic and emergent), a four-factor model of performance and financial performance has been developed (State social support). The construction proposes an orderly set of rules for the organization and interaction of the constituent elements of the system of social capital development in the economic emergence, where sub- particles with integrative relationships and influencing factors are distinguished. The results of the four factor model present a scientific and practical approach to calculating the systemic effect (synergistic and emergent effects) in the form of the results of the implementation of the properties of the system, which could not be predicted by direct calculation of the sum of the components of the system as a whole. Four factor models applied methods for detecting the isolated influence of chain substitution factors and logarithmic methods. The simulation method presented on macroeconomic factors influencing the development of social capital of Ukraine has been tested. The system of conditions for effective budget funding (financial support) for the development of social capital is presented, influencing the increase of positive and negative systemic effects.
\end{abstract}

Key-Words: modeling; factors; budget funding (financial support); social capital; social support, protection; social investment; systemic effect; synergistic and emergent effects; economic emergence.

Received: November 23, 2020. Revised: March 14, 2021. Accepted: April 1, 2021. Published: April 12, 2021.

\section{Introduction}

Methodological framework for the development of social capital in the economic emergence as an institutional system based on an innovative approach and the strengthening of system-based factors of the knowledge economy, the information society, The digital economy, robotics and artificial intelligence, behavioural economics, and neuroeconomics have not been sufficiently reflected in modern scientific research, so it is worth noting and detailing these processes. The paradigm for the development of social capital is based on social relations and goes beyond neoclassical theory, combining non-traditional and non-economic factors that potentially affect a nation's economic growth. The methodological basis of research on social capital development is the processes of institutional formation, which is based on general approaches of 
system theory, mirror theory, systems analysis, chaos, graphs, fuzzy sets, taxonomic analysis, concepts of modelling complex multiple agent systems and synergies.

The system for the development of social capital forms a certain integrity of the object and is an orderly set of rules for the organization and interaction of the constituent elements, where subparticles are distinguished with certain integration relationships and influencing factors among them. A key feature of the system is the hierarchy and subordination of the levels of behaviour of its agents. A set of interacting actors operating under the rules and regulations of institutions with a developed institutional environment ensure the development of social capital.

In the focus of the development and content of the new economy, integrative and systemic thinking is emerging, which makes it necessary to update the existing methodology of research on the development of social capital. Under the influence of robotization and digital processes in the economy there are emergent effects (properties) of digital progress that expand the possibilities of the intellectualization of control systems.

\section{Literature Review}

The main resource for the accumulation and development of social capital is the knowledge, skills and interaction of citizens in society, in order to maximize the competitiveness of the country and entrepreneurship as an important budget of the national economy; development of social capital. It is social capital that drives and drives innovation in economic emergence.

Chon K., Park E., \& Zoltan J. [1] note that the circle of economic, cultural and social capital is the drivers of the modern sphere of hospitality and attraction of tourism in Asia. Cholifah S. [2] used the perspective of Robert K. Merton's theory of structural function to identify the effects of the hidden function of social capital changes on a country's development, highlighting the positive and negative characteristics of the results. Caruso L., \& Cini L. [3] link social movements to the capital chain as the basis of formation to include the formation of macro-social theory. Samila, S., \& Sorenson, O. [4] emphasize the importance of social integration as an important driver of the interconnection of society, which is the basis for the realization of venture capital. Venture capital contributes to innovation, enterprise development and economic growth in the country.

Bassi A. M. [5] are the basic building blocks of the green economy model, bringing social capital together with physical, human and natural capital. Without modelling processes, it is impossible to measure the amount of social capital sold in the country. The scientific heritage of Voynarenko M. and other co-authors [6-11] focuses on modelling socio-economic processes and influences on the development of the country's economy and its components of emergent characteristics of the development and development of the country as a whole. Kenny D. C. [12] presented a simulation system for detecting the impact on business and households from various types of capital, including social. Caïs J., Torrente D., and Bolancé C. [13] modeled the processes of analysis of the influence of factors on social and institutional potential in the conditions of unstable environment and economic crisis. The case study focuses on the results of the global economic crisis (2008) on the example of Spain. Ávila R. C., \& Campos J. L. M. [14] under the conditions of formation of social economy and realization of the consolidated concept of development of the socially-oriented approach of public administration, allocate importance of social investments, innovation and enterprises, economy of solidarity, economy of cooperation, circular economy and common good, it is implemented through the concept of social responsibility.

Bao G., Zeng F., Wang M. [15] proposed in their study software (DEA model) to identify efficiencies in the structuring and allocation of human resources for the purpose of increasing bank profits, taking into account the effect of scale. This assumption reinforces the assertion of the relationship between social interaction and the efficiency of the economic system. Eldar A. G. [16] considers socio-economic development through the prism of sustainable development in Azerbaijan. Based on the study, the author chose sustainable financial and investment support for the development of social capital.

Having considered the research of scientists in this field, the authors try to systematize knowledge and identify the main driver in the financial support of social capital development in this article. The defined goal is to investigate the importance of influencing factors and to describe the nature of the resulting phenomena, namely systemic effects. The productive force of stimulation and influence on the final output in the form of value added of a product, goods and services is the level of provision of social benefits within companies when social capital is realized. Therefore, when considering the specific characteristics and possibilities of realization of social capital through economic-mathematical modelling in the context of the emergent economy, it is necessary to take into account not only the skills 
acquired by specialists, the level of competence and trust, The impact of the level of financial support and the provision of social protection for the population is reflected in the performance of enterprises and organizations.

\section{Methodology}

The system of social capital development in emergent economies focuses on financial support and social interaction in professional activities. It requires adaptability and flexibility, from banking to drawing. In the development paradigm of social capital, non-traditional and non-economic factors include: digital, information, technology, environmental, energy, neuropsychological, neurolinguistic, ethical, cultural and religious factors, political-institutional and other. Natural and developed elements are considered among the main features of the social capital development system. Naturally: the potential for interaction or social resources when workers achieve the results of the enterprise's activities; capacity to accumulate - to create social networks; convertibility as exchange without equivalence; capacity to exchange for other resources in quantitative terms; liquidity as a possibility of exchange on an equivalent basis; profitability as savings of transaction costs of cooperation or social rents.

The developed elements of social capital are: corporate qualities, including the ability to work as a team; orientation towards new knowledge and selfdevelopment; adaptive and communicative capacities (emotional and adaptive intelligence); respect for moral norms and conduct;

Acquired general and special (professional, subject) competences form integral competence.

In the social capital development system, the emergent economy concentrates all levels of social success of the individual in the economic system, including IQ (intelligence quotient) and EQ (emotional quotient) which include such important features as the development of AQ (adaptability quotient), ability to think critically and creatively, be cognitively flexible, solve complex problems, apply an effective system of coordination of people in social relationships, reflection, the ability to recognize customer needs and hear the peculiarities of demand, the art of productive negotiation.

Adaptive Intelligence (quotient) becoming an innovative factor of individual success (economic agent) manifest in its purposefully developed ability to respond effectively to any changes in the business environment and to maximize the results of the development strategy.
As noted by BBC experts the «ideal candidate must have three components» [17], that is, the key components of the ideal candidate (economic agent) are: IQ, which helps to pass exams for qualification; $\mathrm{EQ}$, which is responsible for communication with the interviewer, when he finds work and develops future relationships with clients and colleagues; with changes in the system or in the changing operating environment (e.g., automation, digitization), there is a need to adapt or manifest AQ adaptive intelligence, who is in charge of how to play a role under the new conditions. All three profile rates of the ideal candidate complement each other to help solve problems and adapt. The achievement of such a three-component set of qualities by the candidate (economic agent) is a positive emergent effect of personal development.

Among the basic performance indicators of the social capital development system in the economic system are the following indicators developed by R. Harper (2002), namely: social activities (number of social agents, number of members of voluntary and voluntary organizations, social activity of members of organizations); social relations and interactions (frequency of meetings with family, colleagues, friends, neighbors, intensity of social networking, number of social agents, count on help, number of social agents, ready to provide help, level of satisfaction of living space); trust and social norms (level of trust in the environment at the level of the microenvironment and environment, level of general social interaction, perception of common cultural values); social activity (level of confidence in State institutions, public institutions and authorities at all levels; perception of the possibility of influencing events, social responsibility, level of awareness of State and local affairs, state of affairs, participation in initiative groups, participation in elections, vote); common norms and values (attitude to views, traditions in the territory of residence, level of satisfaction with the place of activity and infrastructure; satisfaction with work, social and labour relations, life, level of responsibility for the state of the social and labour sphere and social support).

Specific performance indicators of the social capital development system that highlight the special characteristics of achieving systemic effects of behaviour and interaction of agents (economic agents) in the beneficiary economy are: level of adaptive intelligence of subjects (economic agents) in unpredictable operating conditions (speed of adaptation, communication, speed of restoration of «resilience», stress resistance); digital culture, ethics, tolerance and virtual patience; creation, self- 
organization and self-development of subjects in the world of VUCA; reflex (analysis of own understanding of education and learning); transition from a focus economy to a participatory economy (emotional bonding and social skills development through attraction); ceative and critical thinking; commercialization and knowledge management in the economic system.

To measure social capital and the level of its development, fuzzy logic models are used (to identify intangible assets and factors that are difficult to measure by value), correlation-regression models (to study a number of data and dynamic analysis), structural models with indices (for estimates of coefficients of relative importance based on expert assessments), hierarchical multidimensional models (to identify relationships and their strength), models of intellectual-creative paradigm (to describe cognitive creativity). But some of these models are based on intangible and non-financial data, which do not reflect the connection with the result of the sale of social capital - increased value added and efficiency in the national economy (GDP).

For the purposes of solving the problem of optimization of resources, the authors chose a method that allows you to select and calculate the amount of impact on the overall result, with both positive and negative. In order to identify the systemic effect at the level of one country and fiscal policy, a method of identifying the isolated influence of factors, which identifies different levels of influence of factors.

The scheme of evaluation methodology and return on financial support for the development of social capital is presented in Fig. 1.

Measuring and estimating the effects of social capital sales at the macroeconomic level is often reduced to econometric modelling to identify innovation effects based on the Cobb-Douglas value added function, establishing a link between costs and innovation. For example, Perez F. and the authors [18] team presented an econometric model of social accumulation as an empirical index:

$$
s k_{i t}^{*}=\beta\left(\frac{1+\lambda(N-1)}{N}\right) \frac{y_{t}}{\bar{w}_{t} C\left(I_{i t}\right)}(1-G) \frac{1-\left(\frac{\partial}{1+\rho}\right)^{T-t}}{1+\rho-\delta},
$$

When measuring the systemic effect of social capital, such a model depends directly and positively on the income $y t$ approximated by GDP; it depends back on the $G$ income inequality approximated by the RGI (Regional Gini Index), as inequality and the risk of exclusion in the consumption of collective income increase; which creates a positive dependence on life expectancy $T$, as it increases the participation of society in social networks; accordingly, the level of wages has a negative impact $\overline{\mathrm{W}}_{\mathrm{i}}$; negatively affected by the marginal cost of interaction $C^{\prime}(I s)$, the approximate share of people of working age with higher education; from the level of depreciation of social capital $\mathrm{d}(\delta=(1-\mathrm{d})$, rate of return on investment in social capital), approximated by the level of unemployment; and discount factor $\rho$, rate of $4 \%$.

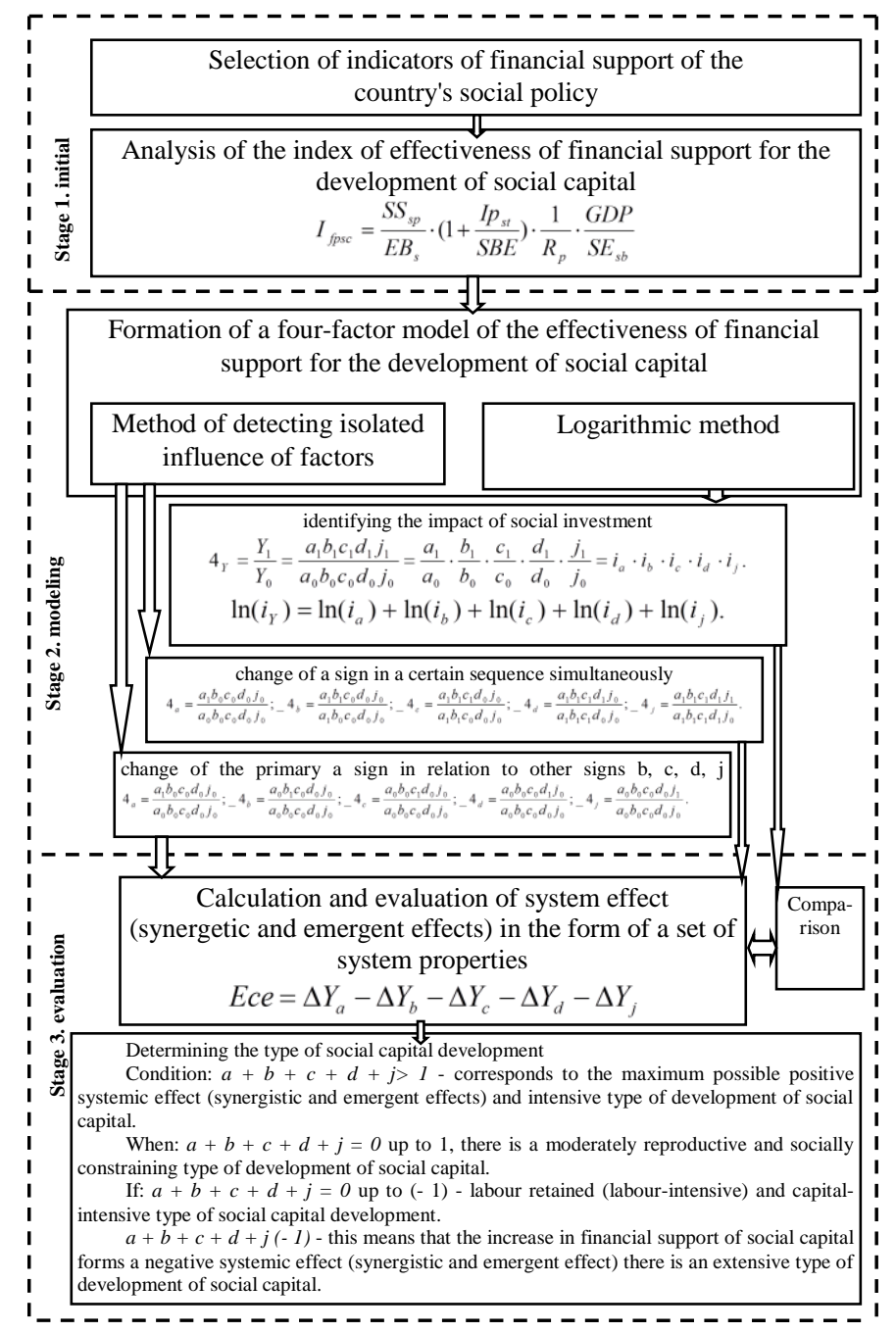

Fig. 1. Scheme of evaluation methodology and return on financial support for the development of social capital Source: Authors' results.

The parameter $\beta$ of the Cobb-Douglas production function per worker can be estimated from the national accounts.

The exponentially multiplied three factor model for the $\beta$ Cobb-Douglas production function per worker can be estimated from the National Accounts of Financial Support for Social Development indicators, which includes the share of social support and protection in the state budget, the profitability of enterprises in the country (sales and 
the ratio of GDP) and the profitability of social expenditures of the state budget is determined by the formula:

$$
I_{f s p}=\frac{S S_{s p}}{E B_{s}} \cdot \frac{1}{R_{p}} \cdot R_{s e}=\frac{S S_{s p}}{E B_{s}} \cdot \frac{1}{R_{p}} \cdot \frac{G D P}{S E_{s b}} ;
$$

where the $I_{f s p}$ is an index of the financial return on social support and social protection; the $S S_{S P}$ is the volume of social support and social protection, millions of UAH; $E B_{s}$ - state budget expenditure, millions of UAH. $1 / R_{p}$ is the inverse measure of profitability (loss) of all business activities; $R_{s e}$ is the profitability of social expenditures of the State budget (Ratio of $G D P$ to $S E_{s b}$ of social expenditures of the State budget).

In our opinion, to identify the impact of the effectiveness of social policy on the development of social capital, we propose a four-factor model based on identifying the effectiveness and impact of budget funding (financial support) to achieve synergistic and new implications for the development of social capital, which is as follows:

$$
I_{f p s c}=\frac{S S_{s p}}{E B_{s}} \cdot\left(1+\frac{I p_{s t}}{S B E}\right) \cdot \frac{1}{R_{p}} \cdot \frac{G D P}{S E_{s b}}
$$

where $I_{f p s c}$ is the index of the financial performance of the development of social capital; $I p_{s t}$ is the income part of the budget payments from the revenue of social taxes (single social contribution, taxes and military tax on the income of individuals), millions of UAH. SBE - state budget expenditure on health care, spiritual and physical development, education and social support and protection, millions of UAH.

The four Social Capital Performance Models serve to identify systemic effects, such as synergistic and emergent effects, by identifying the isolated effects of chain substitution.

In the first variant, the system is represented in the form where the primary character $a$ changes in relation to the other features $b, c, d, j$ (changes not simultaneously, but in a certain sequence), and the following changes of the latter features are modified in accordance with the original feature. Factor changes shall be plotted as follows:

$$
4_{a}=\frac{a_{1} b_{0} c_{0} d_{0} j_{0}}{a_{0} b_{0} c_{0} d_{0} j_{0}} ;-4_{b}=\frac{a_{0} b_{1} c_{0} d_{0} j_{0}}{a_{0} b_{0} c_{0} d_{0} j_{0}} ;-4_{c}=\frac{a_{0} b_{0} c_{1} d_{0} j_{0}}{a_{0} b_{0} c_{0} d_{0} j_{0}} ;-4_{d}=\frac{a_{0} b_{0} c_{0} d_{1} j_{0}}{a_{0} b_{0} c_{0} d_{0} j_{0}} ;-4_{j}=\frac{a_{0} b_{0} c_{0} d_{0} j_{1}}{a_{0} b_{0} c_{0} d_{0} j_{0}} \text {. }
$$

In the second variant, the calculation of the system, where the features change in a certain sequence at the same time, with subsequent changes in the latter features change to take into account the primary. Accordingly, factor changes are based on the scheme:

$$
4_{a}=\frac{a_{1} b_{0} c_{0} d_{0} j_{0}}{a_{0} b_{0} c_{0} d_{0} j_{0}} ;-4_{b}=\frac{a_{1} b_{1} c_{0} d_{0} j_{0}}{a_{1} b_{0} c_{0} d_{0} j_{0}} ;-4_{c}=\frac{a_{1} b_{1} c_{1} d_{0} j_{0}}{a_{1} b_{1} c_{0} d_{0} j_{0}} ;-4_{d}=\frac{a_{1} b_{1} c_{1} d_{1} j_{0}}{a_{1} b_{1} c_{1} d_{0} j_{0}} ;-4_{j}=\frac{a_{1} b_{1} c_{1} d_{1} j_{1}}{a_{1} b_{1} c_{1} d_{1} j_{0}} .
$$

Absolute private increments of the resultoriented feature $\Delta \mathrm{Y}$ when the primary $a$ trait changes relative to the other attributes $b, c, d, j$ by the five factors of the inverse chain substitution method as the difference between the numerator and the denominator of the corresponding index is defined as follows:

$$
\begin{aligned}
& \Delta Y_{a}=a_{1} b_{0} c_{0} d_{0} j_{0}-a_{0} b_{0} c_{0} d_{0} j_{0} ; \\
& \Delta Y_{b}=a_{0} b_{1} c_{0} d_{0} j_{0}-a_{0} b_{0} c_{0} d_{0} j_{0} ; \\
& \Delta Y_{c}=a_{0} b_{0} c_{1} d_{0} j_{0}-a_{0} b_{0} c_{0} d_{0} j_{0} ; \\
& \Delta Y_{d}=a_{0} b_{0} c_{0} d_{1} j_{0}-a_{0} b_{0} c_{0} d_{0} j_{0} ; \\
& \Delta Y_{j}=a_{0} b_{0} c_{0} d_{0} j_{1}-a_{0} b_{0} c_{0} d_{0} j_{0} .
\end{aligned}
$$

Absolute private increments of the resultoriented feature $\Delta Y$, where features change in a sequence simultaneously by five factors in the inverse chain substitution method as the difference between the numerator and the denominator of the index concerned is defined as follows:

$$
\begin{aligned}
& \Delta Y_{a}=a_{1} b_{0} c_{0} d_{0} j_{0}-a_{0} b_{0} c_{0} d_{0} j_{0} ; \\
& \Delta Y_{b}=a_{1} b_{1} c_{0} d_{0} j_{0}-a_{1} b_{0} c_{0} d_{0} j_{0} ; \\
& \Delta Y_{c}=a_{1} b_{1} c_{1} d_{0} j_{0}-a_{1} b_{1} c_{0} d_{0} j_{0} ; \\
& \Delta Y_{d}=a_{1} b_{1} c_{1} d_{1} j_{0}-a_{1} b_{1} c_{1} d_{0} j_{0} ; \\
& \Delta Y_{j}=a_{1} b_{1} c_{1} d_{1} j_{1}-a_{1} b_{1} c_{1} d_{1} j_{0} .
\end{aligned}
$$

The logarithm method presents a four-factor model of the financial performance of social capital development in a country (impact of social investment) as follows:

$$
4_{Y}=\frac{Y_{1}}{Y_{0}}=\frac{a_{1} b_{1} c_{1} d_{1} j_{1}}{a_{0} b_{0} c_{0} d_{0} j_{0}}=\frac{a_{1}}{a_{0}} \cdot \frac{b_{1}}{b_{0}} \cdot \frac{c_{1}}{c_{0}} \cdot \frac{d_{1}}{d_{0}} \cdot \frac{j_{1}}{j_{0}}=i_{a} \cdot i_{b} \cdot i_{c} \cdot i_{d} \cdot i_{j} .
$$

The logarithms of the left and right parts of the ratio will look like this:

$$
\ln \left(i_{Y}\right)=\ln \left(i_{a}\right)+\ln \left(i_{b}\right)+\ln \left(i_{c}\right)+\ln \left(i_{d}\right)+\ln \left(i_{j}\right) .
$$

The logarithmic method does not highlight the synergistic effect of the cumulative effects of the factors. When constructing deterministic models of the multiplicative type to identify the increase in performance by key factors of influence, consider statistical and mathematical models, which are based on different research methods. Methods of chain substitutions and detection of isolated influence of factors, differential, integral and logarithmic methods are used. The authors used two methods that best highlight the contribution of the interaction of the main factors.

\section{Empirical results and discussion}

Function calculations looks like this: $\ln \left(i_{Y}\right)_{2017}=-2,049+(-0,134)+(-1,609)+(-0,241)+(-0,162)=-4,195$ $\ln \left(i_{Y}\right)_{2018}=-0,422+(-0,089)+(-0,405)+0,059+0,034=-0,824$ $\ln \left(i_{Y}\right)_{2019}=-0,613+(-0,052)+(-0,624)+0,029+0,084=-1,176$

The absolute partial increments of the resultoriented feature $\Delta \mathrm{Y}$ by logarithm, where the features change simultaneously, have the following form: 


$$
\begin{aligned}
\Delta Y_{a_{i}} & =\frac{\ln \left(i_{a}\right)_{i}}{\ln \left(i_{Y}\right)_{i}} ; \Delta Y_{a 2017}=\frac{-2,049}{-4,195}=0,488 ; \Delta Y_{a 2018}=\frac{-0,442}{-0,824}=0,513 ; \Delta Y_{a 2019}=\frac{-0,613}{-1,176}=0,521 ; \\
\Delta Y_{b i} & =\frac{\ln \left(i_{b}\right)_{i}}{\ln \left(i_{Y}\right)_{i}} ; \Delta Y_{b 2017}=\frac{-0,134}{-4,195}=0,032 ; \Delta Y_{b 2018}=\frac{-0,089}{-0,824}=0,107 ; \Delta Y_{b 2019}=\frac{-0,052}{-1,176}=0,044 ; \\
\Delta Y_{c i} & =\frac{\ln \left(i_{c}\right)_{i}}{\ln \left(i_{Y}\right)_{i}} ; \Delta Y_{c 2017}=\frac{-1,609}{-4,195}=0,384 ; \Delta Y_{c 2018}=\frac{-0,405}{-0,824}=0,492 ; \Delta Y_{c 2019}=\frac{-0,624}{-1,176}=0,531 ; \\
\Delta Y_{d i} & =\frac{\ln \left(i_{d}\right)_{i}}{\ln \left(i_{Y}\right)_{i}} ; \Delta Y_{d 2017}=\frac{-0,241}{-4,195}=0,057 ; \Delta Y_{d 2018}=\frac{0,059}{-0,824}=-0,071 ; \Delta Y_{d 2019}=\frac{0,029}{-1,176}=-0,025 ; \\
\Delta Y_{j_{i}} & =\frac{\ln \left(i_{j}\right)_{i}}{\ln \left(i_{Y}\right)_{i}} ; \Delta Y_{j_{2017}}=\frac{-0,162}{-4,195}=0,039 ; \Delta Y_{j_{2018}}=\frac{0,034}{-0,824}=-0,041 ; \Delta Y_{j_{2019}}=\frac{0,084}{-1,176}=-0,071 .
\end{aligned}
$$

\begin{tabular}{|c|c|c|c|c|c|}
\hline \multirow[b]{2}{*}{ Indicator } & \multicolumn{5}{|c|}{ year } \\
\hline & 2016 & 2017 & 2018 & 2019 & $\begin{array}{c}\text { Absol } \\
\text { ute } \\
\text { deduct } \\
\text { ion201 } \\
9 \text { to } \\
2016 \\
\end{array}$ \\
\hline GDP, millions of UAH & $\begin{array}{c}2383 \\
182\end{array}$ & $\begin{array}{c}2982 \\
920\end{array}$ & $\begin{array}{c}3558 \\
706\end{array}$ & $\begin{array}{c}3974 \\
564\end{array}$ & $\begin{array}{c}1591 \\
382\end{array}$ \\
\hline $\begin{array}{l}\text { State budget expenditures, } \\
\text { millions of UAH }\end{array}$ & $\begin{array}{c}835832, \\
1 \\
\end{array}$ & $\begin{array}{c}1056973 \\
, 1\end{array}$ & $\begin{array}{c}1250173 \\
, 5\end{array}$ & 1370113 & $\begin{array}{c}534280 \\
9\end{array}$ \\
\hline $\begin{array}{l}\text { Social expenditures of the state } \\
\text { budget, millions of UAH (social } \\
\text { support and social protection, } \\
\text { health care, spiritual and } \\
\text { physical development, } \\
\text { education), including: }\end{array}$ & $\begin{array}{c}370842 \\
80\end{array}$ & $\mid \begin{array}{c}590412 \\
20\end{array}$ & $\begin{array}{c}664233 \\
70\end{array}$ & $\begin{array}{c}720471 \\
70\end{array}$ & $\begin{array}{c}349628 \\
9\end{array}$ \\
\hline $\begin{array}{l}\text { social support and social } \\
\text { protection, millions of UAH }\end{array}$ & $\begin{array}{l}2583 \\
26,1 \\
\end{array}$ & \begin{tabular}{r|}
2857 \\
61,7 \\
\end{tabular} & $\begin{array}{l}3093 \\
63,6 \\
\end{array}$ & $\begin{array}{l}3217 \\
86,6 \\
\end{array}$ & $\begin{array}{c}6346 \\
0,50 \\
\end{array}$ \\
\hline $\begin{array}{l}\text { Personal income tax and military } \\
\text { duty, millions of UAH }\end{array}$ & $\begin{array}{c}138781, \\
80\end{array}$ & $\begin{array}{c}185686 \\
10\end{array}$ & $\begin{array}{c}229900 \\
6\end{array}$ & $\begin{array}{c}275458 \\
4\end{array}$ & $\begin{array}{c}136676 \\
6\end{array}$ \\
\hline $\begin{array}{l}\text { Single social contribution, } \\
\text { millions of UAH }\end{array}$ & $\begin{array}{c}1320 \\
00\end{array}$ & $\begin{array}{c}1810 \\
00\end{array}$ & $\begin{array}{l}1968 \\
54,7 \\
\end{array}$ & \begin{tabular}{|l|}
2280 \\
24,9
\end{tabular} & $\begin{array}{c}9602 \\
4,90\end{array}$ \\
\hline $\begin{array}{l}\text { The level of profitability (loss) } \\
\text { of all activities of enterprises, } \%\end{array}$ & 0,6 & 3,0 & 4,5 & 8,4 & 7,8 \\
\hline $\begin{array}{l}\text { Index of state budget revenues } \\
\text { from the social sphere to social } \\
\text { budget expenditures, }(\mathrm{j} 0 \mathrm{j} 1)\end{array}$ & 0,73 & 0,62 & 0,64 & 0,70 & $-0,03$ \\
\hline $\begin{array}{l}\text { The share of expenditures on } \\
\text { social support and protection, } \\
\text { coefficient. (b0 b1) }\end{array}$ & 0,31 & 0,27 & 0,25 & 0,23 & $-0,07$ \\
\hline $\begin{array}{l}\text { Inverse profitability of } \\
\text { enterprises }(\mathrm{c} 0 \mathrm{c} 1)\end{array}$ & 1,67 & 0,33 & 0,22 & 0,12 & $-1,55$ \\
\hline $\begin{array}{l}\text { Profitability of social } \\
\text { expenditures of the state budget } \\
\text { (the ratio of GDP to social } \\
\text { expenditures of the state budget) } \\
\text { (d0 d1) }\end{array}$ & 6,43 & 5,05 & 5,36 & 5,52 & $-0,91$ \\
\hline $\begin{array}{l}\text { Performance index of financial } \\
\text { support for social capital } \\
\text { development }\left(\mathrm{Isc}_{\mathrm{rfs}}\right), \mathrm{UAH}(\mathrm{a} 0 \mathrm{a} 1)\end{array}$ & 5,73 & 0,74 & 0,48 & 0,26 & $-5,47$ \\
\hline
\end{tabular}

Table 1. Dynamics of indicators of financial provision of social capital of Ukraine for 2016-2019 years

Source: Authors' results.

According to the dynamics of financial support of social capital of Ukraine with the annual growth of public social investment there is a slight decrease in the share of expenditures on social benefits (0.07), which further has an impact on reducing the index of income from the social sphere $(-0.03)$, profitability of social expenditures $(-0.91)$, and significantly decreased the inverse indicator of profitability of enterprises (-1.55), which by its economic nature characterizes the resource coverage of the results of enterprises. The general dynamics is negative, and $\mathrm{Isc}_{\mathrm{rfs}}$ decreased by -5.47 , it is 0.26 , which characterizes the low level of efficiency of budget expenditures for the development of social capital in Ukraine, the return is insignificant.

According to the results of the Financial Performance Model for the Development of Social Capital, it is possible to present a calculation of systemic effects (synergistic and emergent effects) as a result that characterizes the set of features of the system, which can not be predicted by the sum of the components of the system as a whole, so the elements, the formula will have the following form:

$$
\text { Ece }=\Delta Y_{a}-\Delta Y_{b}-\Delta Y_{c}-\Delta Y_{d}-\Delta Y_{j}
$$

where Ece - systemic effect (synergistic and emergent effects); $\Delta Y_{a}$ - increase in the performance index of budget funding (financial support) for the development of social capital; $\Delta Y_{b}$ - increase in the share of expenditure on social support and protection; $\Delta Y_{c}$ - increase in the inverse rate of profitability of a country's enterprises; $\Delta Y_{d}$ increase in the profitability of social expenditure in the State budget; $\Delta Y_{j}$ - Increase in the index of State budget income from the social sphere to the social expenditure of the State budget.

Using the isolated influence method and the logarithmic method, Table 2 presents the changes in returns due to certain economic factors.

Condition: $a+b+c+d+j>1$ - corresponds to the maximum possible positive systemic effect (synergistic and emergent effects) and intensive type of development of social capital.

When: $a+b+c+d+j=0$ up to 1 , there is a moderately reproductive and socially constraining type of development of social capital.

If: $a+b+c+d+j=0$ up to (-1) - labour retained (labour-intensive) and capital-intensive type of social capital development.

$a+b+c+d+j(-1)-$ this means that the increase in financial support of social capital forms a negative systemic effect (synergistic and emergent effect) there is an extensive type of development of social capital.

Under the condition of change of the primary a sign, the greatest negative influence on the factor variable $I_{p c i}-12.06$ by the method of isolated influence is exerted by the indicators $P_{c b}$ and $j$ with the values $-2,960$. Variable $b$ has a medium level of influence and insignificant $\mathrm{c}$ with a value of $-1,734$. That is, when the budget revenues from the social sphere and the profitability of social expenditures decrease, the effectiveness of financial support for the development of social capital decreases. Given the change of $a, b, c, d, j$ features at the same time 
has the greatest impact on the profitability of social expenditures of the state budget. It is the driver of social capital development.

Table 2. Modeling of the system effect and factor analysis of the effectiveness of budget funding (financial support) for the development of social capital in Ukraine for 2016-2019 (based on the index multiplicative four-factor model)

\begin{tabular}{|c|c|c|c|c|c|c|}
\hline \multirow{3}{*}{ Indicator } & \multicolumn{4}{|c|}{$\begin{array}{c}\text { Method of detecting isolated influence of } \\
\text { factors }\end{array}$} & \multirow{2}{*}{\multicolumn{2}{|c|}{$\begin{array}{c}\begin{array}{c}\text { Logarithmic } \\
\text { method }\end{array} \\
\begin{array}{c}\text { Subject to changes } \\
\text { in a, b, }, \mathbf{d}, \mathbf{j} \\
\text { features }\end{array} \\
\text { simultaneously }\end{array}$}} \\
\hline & \multicolumn{2}{|c|}{$\begin{array}{c}\text { Provided that the } \\
\text { primary a sign } \\
\text { changes in relation } \\
\text { to other signs b, } c \text {, } \\
\quad d, j\end{array}$} & \multicolumn{2}{|c|}{$\begin{array}{c}\text { Under the condition } \\
\text { of change of a, b, c, } \\
d, j \text { signs in a certain } \\
\text { sequence } \\
\text { simultaneously } \\
\end{array}$} & & \\
\hline & $\begin{array}{c}\text { Factor } \\
\text { variable }\end{array}$ & $\Delta \mathbf{Y}$ & $\begin{array}{c}\text { Factor } \\
\text { variable }\end{array}$ & $\Delta \mathbf{Y}$ & Ln (i) & $\Delta \mathbf{Y}$ \\
\hline \multicolumn{7}{|c|}{$\begin{array}{l}\text { Index of effectiveness of budget funding (financial support) for the development } \\
\text { of social capital }\left(I_{p c i}\right), a\end{array}$} \\
\hline $2017 / 2016$ & 0,129 & $-12,06$ & 0,129 & \begin{tabular}{|l|}
$-12,06$ \\
\end{tabular} & $-2,049$ & 0,488 \\
\hline $2018 / 2017$ & 0,656 & $-0,072$ & 0,656 & $-0,072$ & $-0,422$ & 0,513 \\
\hline $2019 / 2018$ & 0,541 & $-0,042$ & 0,541 & $-0,042$ & $-0,613$ & 0,521 \\
\hline \multicolumn{7}{|c|}{ Share of social support and protection expenditures, b } \\
\hline $2017 / 2016$ & 7,844 & $-2,069$ & 1,011 & $-0,267$ & $-0,134$ & 0,032 \\
\hline $2018 / 2017$ & 1,188 & 0,007 & 0,779 & 0,005 & $-0,089$ & 0,107 \\
\hline $2019 / 2018$ & 0,753 & 0,008 & 0,408 & 0,004 & $-0,052$ & 0,044 \\
\hline \multicolumn{7}{|c|}{ The inverse of the profitability of enterprises $(1 / P n), c$} \\
\hline $2017 / 2016$ & 0,875 & $-1,734$ & 0,875 & $-0,190$ & $-1,609$ & 0,384 \\
\hline $2018 / 2017$ & 0,915 & $-0,018$ & 0,915 & $-0,012$ & $-0,405$ & 0,492 \\
\hline $2019 / 2018$ & 0,949 & $-0,005$ & 0,949 & $-0,003$ & $-0,624$ & 0,531 \\
\hline \multicolumn{7}{|c|}{$\begin{array}{l}\text { Profitability of social expenditures of the state budget } \\
\text { (ratio of GDP to social expenditures of the state budget) }\left(P_{c B}\right), d\end{array}$} \\
\hline $2017 / 2016$ & 0,200 & $-2,960$ & 0,200 & $-2,960$ & $-0,241$ & 0,057 \\
\hline $2018 / 2017$ & 0,667 & 0,013 & 0,667 & 0,013 & 0,059 & $-0,071$ \\
\hline $2019 / 2018$ & 0,536 & 0,003 & 0,536 & 0,003 & 0,029 & $-0,025$ \\
\hline \multicolumn{7}{|c|}{$\begin{array}{l}\text { Index of state budget revenues from the social sphere in relation to social budget } \\
\text { expenditures, } j\end{array}$} \\
\hline $2017 / 2016$ & 0,786 & $-2,960$ & 0,786 & \begin{tabular}{l|l|}
$-0,057$ \\
\end{tabular} & $-0,162$ & 0,039 \\
\hline $2018 / 2017$ & 1,060 & 0,013 & 1,060 & 0,005 & 0,034 & $-0,041$ \\
\hline $2019 / 2018$ & 1,030 & 0,003 & 1,030 & 0,001 & 0,084 & $-0,071$ \\
\hline \multicolumn{5}{|c|}{ Synergetic and emergent effects } & \multicolumn{2}{|c|}{$\ln \left(i_{Y}\right)$} \\
\hline $2017 / 2016$ & - & $-2,34$ & - & $-8,59$ & $-4,195$ & 1 \\
\hline $2018 / 2017$ & - & $-0,09$ & - & $-0,08$ & $-0,824$ & 1 \\
\hline $2019 / 2018$ & - & $-0,05$ & - & $-0,05$ & $-1,176$ & 1 \\
\hline
\end{tabular}

Given the change of $a, b, c, d, j$ features simultaneously by the logarithmic method, the greatest impact on $I_{p c i}-2,049$ has c (inverse of the profitability of enterprises in the national economy, or coverage ratios). That is, resources spent (including social capital) on the production of goods, goods and services. However, the logarithmic method does not reflect the systemic effect, but is more sensory, so we focus on the results of the method of isolated influence.

Analysis of the systemic effect of changes in the effectiveness of financial support of social capital development in Ukraine for 2016-2019 shows negative changes in the structure of social expenditures for social support and protection of the population, the indicators of the index of financial support of social capital development are negative (in $2017-8,59$, in $2018-0.08$, in $2019-0.05$ ). The increase in the financial support of social capital in
Ukraine creates a negative systemic effect (synergetic and emergent effect) and is an extensive type of social capital development. Since the decrease in the index of effectiveness of financial support for the development of social capital has a negative systemic effect in the ratio $(-12.06)$ to $(-8.59)$, almost 3:2.

This situation is due to the failure to take advantage of social capital. The reduction in life expectancy, the deterioration in the health of the population, the lack of realization of the intellectual capital of society and the lack of necessary measures of support from the State should be mentioned as contributing factors, Reduction of the number of highly qualified personnel, absence of a perfect system of training and retraining of personnel in enterprises that would meet the requirements of modern technological development, discrepancy between the level of development of science and technology, etc.

A characteristic feature is the instantaneous reaction of the society to changes in the financial provision, that is, in the first year of the introduction of changes in social support there is a bifurcation, after which the social tension decreases, which proves the existence of an adaptation or adaptive intelligence effect in Ukrainian. The number of economic factors influencing social capital plays an important role. The more the channels of budget funding (financial support) for the development of social capital are widened, the greater the influence on the increase of negative systemic effects, that is, public discontent, negative empathy and mistrust increase.

\section{CONCLUSION}

This study examined the performance of the system of budget funding (financial support) for the development of social capital using the example of Ukraine. The establishment of an integrated system for the development of social capital - a four-factor model for measuring the effectiveness of social support financing and protection in a country The application of which will enable the reproduction of social capital and achieve the best results in its realization.

On the basis of the author's multiplier model of the Financial Performance Index for the Development of Social Capital by Measure of Profitability (Loss) of All Activities of Enterprises and Profitability of Social Expenditures of the State Budget has been proved, that an increase in the share of financial support significantly affects the efficiency of the realization of social capital. In the 
process of factor analysis presented by Ukraine, the model reveals a close relationship between the indicators of profitability of enterprises and GDP and the financial indicators of social support and protection of the population. After calculations, it can be said that the national system for the development of social capital is of an extensive type, involving insufficient use of social capital.

\section{References:}

[1] Chon, K., Park, E., \& Zoltan, J. (2020). The Asian Paradigm in Hospitality and Tourism. Journal of Hospitality and Tourism Research, 44(8), 11831202. https://doi.org/10.1177/1096348020945370

[2] Cholifah, S. (2017). Perubahan sosial masyarakat desa jamprong pasca pendirian smp satu atap. Paradigma, 5(3).

[3] Caruso, L., \& Cini, L. (2020). Rethinking the Link Between Structure and Collective Action. Capitalism, Politics, and the Theory of Social Movements. Critical Sociology, 46(7-8), 10051023. https://doi.org/10.1177/0896920520911434.

[4] Samila, S., \& Sorenson, O. (2017). Community and Capital in Entrepreneurship and Economic Growth. American Sociological Review, 82(4), 770-795. https://doi.org/10.1177/0003122417711699

[5] Bassi, A. M. (2015). Moving towards integrated policy formulation and evaluation: The green economy model. Environmental and Climate Technologies, $\quad 16(1), \quad 5-19$. https://doi.org/10.1515/rtuect-2015-0009.

[6] Voynarenko M., Dzhedzhula V., Yepifanova, I. (2016). Modelling the process of making decisions on sources of financing of innovation activity. Economic AnnalsXXI, 160(7-8),126-129.

[7] Voynarenko M, Dzhedzhula V., Yepifanova I. (2020). Modeling of the process of personnel motivation for innovation activity WSEAS Transactions on Business and Economics, 17, 467477.

[8] Voynarenko, M., Lazebnyk, L., Hurochkina, V., Kovalenko, O. and Menchynska, O. (2020). Modeling Emergence Properties of Economic System. 10th International Conference on Advanced Computer Information Technologies (ACIT), Deggendorf, Germany, 607-612, doi: 10.1109/ACIT49673.2020.9208954.

[9] Voynarenko M., Hurochkina V., Sushkova O., Yepifanova I. (2021). Beneficial ownership chain and its evaluation arrangement. Studies of Applied Economics, 38, (4). http://dx.doi.org/10.25115/eea.v38i4.3991

[10] Voynarenko M, Dzhedzhula V., Hurochkina V., Yepifanova I., Menchynska, O. (2021). Applying Fuzzy Logic to Modeling Economic Emergence WSEAS Transactions on Business and Economics, 18, 424-433. DOI: 10.37394/23207.2021.18.43 https://www.wseas.org/multimedia/journals/econom ics/2021/a865107-012(2021).pdf
Therefore, for high-quality development of the national strategy of social capital development it is expedient to monitor intangible and material incentives of active citizens and youth with previously determined norms and sizes of social support and protection of the population using the authors' index multiplicative four-factor model of social capital development.

[11]Heyets V., Voynarenko M., Dzhedzhula V., Yepifanova I. \& Trocikowski T. (2021) Models and strategies for financing innovative energy saving activities, IOP Conf. Series: Earth and Environmental Science, 628, 012004, doi:10.1088/1755-1315/628/1/012004.

[12] Kenny, D. C. (2017). Modeling of natural and social capital on farms: Toward useable integration. Ecological Modelling. Elsevier https://doi.org/10.1016/j.ecolmodel.2017.04.010/

[13] Caïs, J., Torrente, D., \& Bolancé, C. (2021). The Effects of Economic Crisis on Trust: Paradoxes for Social Capital Theory. Social Indicators Research, 153(1), 173-192. https://doi.org/10.1007/s11205020-02385-w.

[14] Ávila, R. C., \& Campos, J. L. M. (2018). The social economy facing emerging economic concepts: Social innovation, social responsibility, collaborative economy, social enterprises and solidary economy. CIRIEC-Espana Revista de Economia Publica, Social y Cooperativa, (93), 550. https://doi.org/10.7203/CIRIEC-E.93.12901

[15] Bao G., Zeng F., Wang M. (2020). Study on Human Resource Allocation Efficiency Based on DEA Analysis, International Journal of Circuits, Systems and Signal Processing, Volume 14, pp. 826-832.

[16]Eldar A.G. (2020). Problems of Financial and Investment Support Modelling of the Regional Social and Economic Development, WSEAS Transactions on Business and Economics, ISSN / EISSN: 1109-9526 / 2224-2899, Volume 17, Art. \#72, pp. 741-752.

[17] Is 'AQ' more important than intelligence? https://www.bbc.com/worklife/article/20191106-isaq-more-important-than-intelligence

[18] Perez, F., Serrano, L., Montesinos, V., Fernandez, J. (2006) Measurement of social capital and growth. An economic methodology, Documento. Fundacion BBVA. No. 4. 57.

\section{Contribution of individual authors to the creation of a scientific article (ghostwriting policy)}

Viktoriya Hurochkina was formed of research ideas, made general guidance, implemented model design, development of Scheme of evaluation methodology, 
model visualization, data analysis, implementation of modeling in Software, translation.

Anatoly Telnov has organized data collection for modeling, systematization of influencing factors, description of results.

Svitlana Reshmidilova has organized data collection, selection of literary sources and their description.

Larysa Skorobogata has described the order of interaction of charters of influence and interdisciplinary connections of factors, identified key factors of influence, development of stages of an estimation of characteristics of emergence

Liudmyla Bohatchyk was responsible for Literature review and Statistics, worked out the absolute parts of the increments of the output variable.

Natalia Riabinina was responsible for the systematization of statistical data and the preparation of the primary database, a description of the conditions for the effectiveness of building a four-factor model.

\section{Creative Commons Attribution License 4.0 (Attribution $\quad 4.0$ International, CC BY 4.0)}

This article is published under the terms of the Creative Commons Attribution License 4.0 https://creativecommons.org/licenses/by/4.0/deed.en US 